\title{
In vitro Study of Different Physicochemical Properties of Root Canal Sealers
}

\author{
BERNADETTE KEREKES-MATHE1((D) ORCID ID: https://orcid.org/0000-0001-9643-6383), \\ ATTILA-ZSOLT SZOCS ${ }^{2}$, ROBERT LASZLO ${ }^{3}$, ZITA FAZAKAS ${ }^{4}$, \\ MONIKA KOVACS ${ }^{5 *}$, MIHAI POP 5
}

${ }^{1}$ George Emil Palade University of Medicine, Pharmacy, Science, and Technology of Targu Mures, Faculty of Dental Medicine, Department of Department of Morphology of Teeth and Dental Arches; Technology of Dental Prosthesis and Dental Materials, 38 Gh.Marinescu Str., 540139, Targu Mures, Romania

${ }^{2}$ CMI Tinca Mihaela Irina, 682 Main Str., Tomesti, Harghita, Romania

${ }^{3}$ Cabinet Medical de Medicina Dentara Dr. Laszlo Robert, 22 Pta Cseres Tibor, Remetea, Harghita, Romania

${ }^{4}$ George Emil Palade University of Medicine, Pharmacy, Science, and Technology of Targu Mures, Faculty of Dental Medicine, Department of Biochemistry, 38 Gh.Marinescu Str., 540139, Targu Mures, Romania

${ }^{5}$ George Emil Palade University of Medicine, Pharmacy, Science, and Technology of Targu Mures, Department of Odontology and Oral Pathology, 38 Gh.Marinescu Str., 540139, Targu Mures, Romania

Abstract. The ability of root canal sealers to provide apical seal depends on their physicochemical properties. The aim of this study was to investigate and compare physicochemical properties of different root canal sealers. The $\mathrm{pH}$, solubility, dimensional change and flow rate of four commonly used root canal sealers were evaluated. All of the tested sealers showed a significant solubility and dimensional change. The findings of the present study indicated that the calcium-hydroxide based Sealapex has satisfactory physicochemical properties, but from clinical point of view Adseal might be the most suitable for use.

Keywords: root canal sealers, solubility, flow rate, dimensional change

\section{Introduction}

The purpose of the endodontic filling is to seal the root canal against microorganisms. Improper sealing results in the reentry and proliferation of microorganisms, leading to irritation of periapical tissues and jeopardizing the treatment outcome [1]. A suitable sealer will reduce the chances of reinfection of the canal, promote the healing of periapical lesions and prevent leakage. The ideal root filling must be insoluble, biocompatible, and must remain dimensionally stable after being inserted into the canal. By dimensional change of the sealers we mean shrinkage or expansion of the material after setting, expressed as a percentage [2].

Solubility is an undesirable property of endodontic sealers because dissolved ions and disintegrated particles jeopardize the efficiency of the seal by creating gaps between the material and dentin wall [3]. It is an important requirement for root canal filling materials that they are easily adaptable, insoluble, and seal the canal as much as possible, thus minimizing the number of microorganisms entering the canal system [4-6].

Unfortunately, the ideal root filling material has not yet been created. However, using a combination of materials seems to grant us the closest match to an ideal marginal sealing [5]. The most common root canal filling material is guttapercha used in conjunction with a sealer [7]. Guttapercha is an almost ideal root filling material, but when applied alone, it has poor barrier properties and should therefore be used in combination with a sealer to fill the remaining gaps between the guttapercha mass and the canal wall [4]. Unfortunately, most sealers are more or less soluble and shrink during setting. Shrinkage is proportional to volume, so the sealer should always be used in the thinnest possible layer.

\footnotetext{
*email: ti_monikka@yahoo.com
} 
We cannot use sealers alone but only in combination with guttapercha. They are often toxic when freshly mixed, but setting reduces or eliminates toxicity [4]. Their $\mathrm{pH}$ is an important parameter for hard tissue formation and antimicrobial activity, while the flow rate is an essential feature to get the material to all the hidden spaces of the canal anatomy.

Since there are many sealers on the market, in order to achieve the best possible result, we need to know the physicochemical properties, advantages and disadvantages of different pastes. Our aim was to study the solubility, volume change, $\mathrm{pH}$ changes and flow rate of 4 different sealers.

\section{Materials and methods}

The sealers used for this research are listed in Table 1.

Table 1. The sealers examined

\begin{tabular}{c|cc} 
SEALER NAME & SEALER TYPE & MANUFACTURER \\
\hline Adseal & Epoxy-resin & MetaBiomed \\
Forfenan & Formaldehid-resorcinol & Septodont \\
Sealapex & Calcium hydroxide & SybronEndo, Kerr \\
Endomethasone & $\begin{array}{c}\text { zinc oxide-eugenol and } \\
\text { paraformaldehyde }\end{array}$ & Septodont
\end{tabular}

Ten samples of each material were prepared using a silicone mold with a dimension of $5.7 \times 3.4$ $\mathrm{mm}$. The materials were mixed according to the manufacturers' instructions and then placed in the mold. The mold was placed between two glass slabs and a uniform pressure was applied to expel excess material and obtain uniform, smooth surfaced material samples.

The samples thus obtained were subjected to the first measurements after 24 hours. Initial diameter (Do) and thickness (Vo) were measured with a digital caliper, and initial weight (So) with an analytical balance (Partner). Each sample was then incubated at $37^{\circ} \mathrm{C}$ in $2 \mathrm{ml}$ artificial saliva $(\mathrm{pH}=7.98)$. The $\mathrm{pH}$ of the materials was first measured on the fourth day after incubation. The analytical method involves a pH-meter (HANNA HI $4521 \mathrm{pH}$ meter) and two electrodes: a hydronium ion selective glass electrode and a reference electrode in contact with a saturated solution of the metal salt's anion, $\mathrm{Ag} / \mathrm{AgCl} / \mathrm{KCl}$ sat. A precise $p \mathrm{H}$ determination was made by making a differential of potential measurement, $\Delta \mathrm{E}$, of a standard buffer solution whose $p \mathrm{H}$ was known, 4 and 7 , and then comparing that measurement to $\Delta \mathrm{E}$ measurement of a sample of the sample solution, individually for each material sample. The value of $\Delta \mathrm{E}$ is described by the Nernst equation (Figure 1), where $\Delta \mathrm{E}$ means the differential of potential, $\mathrm{R}$ is the universal gas constant $(8,314 \mathrm{~J} / \mathrm{K} . \mathrm{mol}), \mathrm{F}$ is Faraday's constant $(96.485 \mathrm{C} / \mathrm{mol})$ and $\mathrm{T}$ is for the temperature $(\mathrm{K})$. Subsequent measurements were made on days 7,10 and 14 after the first incubation. On these days, prior to repeating the measurements, the samples were dried on absorbent paper for one hour.

$$
\Delta E=\frac{R T}{2,303 F} \times(\text { pH standard }- \text { pHsample })
$$

Figure 1. Formula used for calculating the $\mathrm{pH}$ of the samples

The thickness and diameter of the dried samples were measured using the same digital caliper, and the values obtained were denoted by Vx and Dx respectively. The re-measured mass was denoted by Sx. The change in samples was calculated using the formulas in Figure 2-4 [2,3,8].

Figure 2 shows the formula for calculating the volume change, where $\mathbf{D}_{\mathbf{0}}$ is the initial diameter, $\mathbf{D}_{\mathbf{x}}$ the volume after soaking and $\mathbf{x}$ is the number of days elapsed. 


$$
\text { Volume change }(\%)=\frac{D x-D o}{D o} \times 100
$$

Figure 2. Formula used for calculating the change in volume of the samples

Figure 3 shows the formula for calculating the change in thickness, where $\mathbf{V}_{\mathbf{o}}$ is the initial thickness, $\mathbf{V}_{\mathbf{x}}$ the thickness after soaking and $\mathbf{x}$ is the number of days since the start of soaking.

$$
\text { Thickness change }(\%)=\frac{V x-V o}{V o} \times 100
$$

Figure 3. Formula used for calculating the change in thickness of the samples

Figure 4 shows the formula for calculating the solubility, where $\mathbf{S}_{\mathbf{o}}$ is the initial mass, $\mathbf{S}_{\mathbf{x}}$ the mass after soaking and $\mathrm{x}$ is the number of days that have passed since the re-measurements were made.

$$
\text { Solubility }(\%)=\frac{S o-S x}{S o} \times 100
$$

Figure 4. Formula used for calculating the solubility of the sample

After each measurement, the plastic recipients were always refilled with $2 \mathrm{ml}$ of artificial saliva and returned to the $37^{\circ} \mathrm{C}$ incubator.

To determine the flow rate, an equal amount of $60 \mathrm{mg}$ of each material was used. The paste measured on the analytical balance was then placed between 2 glass slabs for 6 minutes. The mass of the glass sheets was previously weighed and each of them was found to be 150 grams. The second glass slab was used to load the samples. After 6 minutes, the samples were photographed in the same setting. For each sample, 3 images were taken and a millimetric scale was placed on the glass slab for subsequent calibration. The images of the samples were measured using the Image Pro Insight software.

The results were collected in a Microsoft Excel spreadsheet and formulas were used to calculate changes in the parameters, then dependent and independent t-tests (GraphPad InStat) were used to examine intra-group and inter-group differences.

\section{Results and discussions}

Among the examined parameters, Adseal showed a positive change in the diameter of the samples, with a significant increase after the two weeks $(p=0.00001)$ while a significant decrease in diameter was displayed by the Endomethasone samples ( $p<0.00001)$ (Figure 5). For thickness, Endomethasone also showed a significant decrease compared to the initial values and to the other sealers $(p<0.00001)$ (Figure 6). In terms of solubility, Endomethasone samples showed the highest weight loss as early as day 7, which was the highest solubility compared to the other sealers $(p<0.00001)$. Adseal showed a slight weight gain, whereas Forfenan and Sealapex showed moderate solubility (Figure 7). 


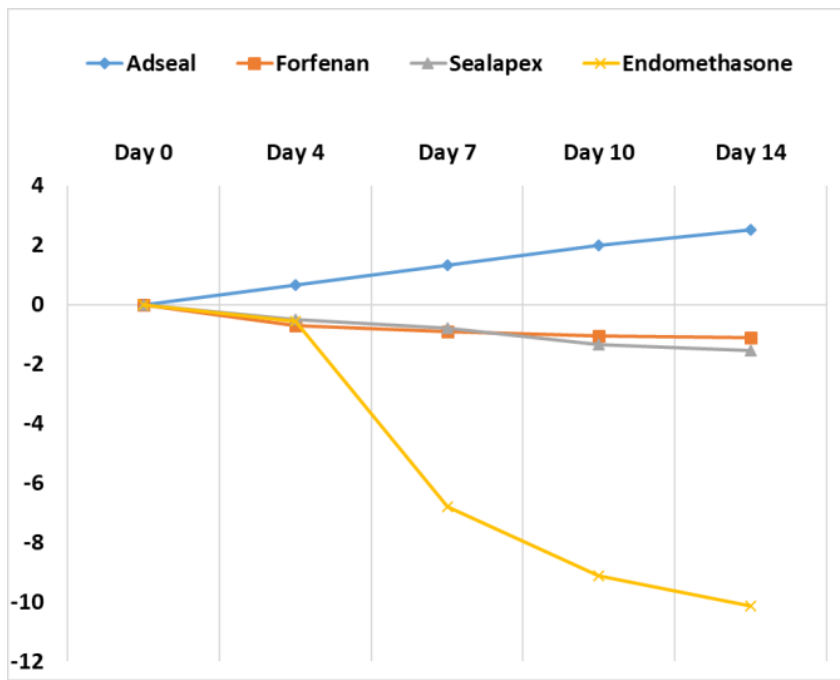

Figure 5. Changes in the diameter of sealer samples

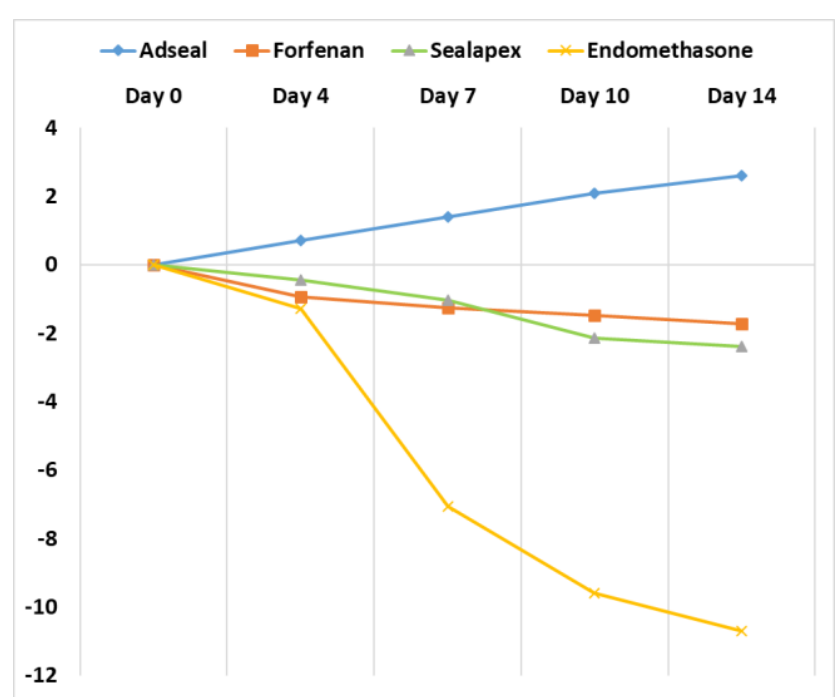

Figure 6. Changes in sample thickness

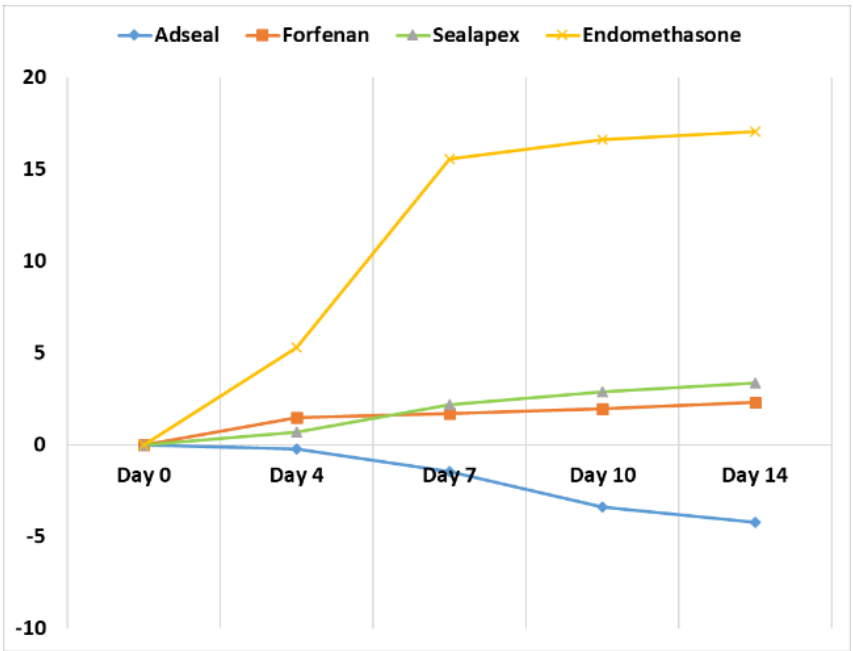

Figure 7. Solubility of the materials

For $p \mathrm{H}$, samples of three sealers (Forfenan, Adseal and Endomethasone) showed a slight decrease, while the $p \mathrm{H}$ of the Sealapex samples increased by day 14 (Figure 8). 


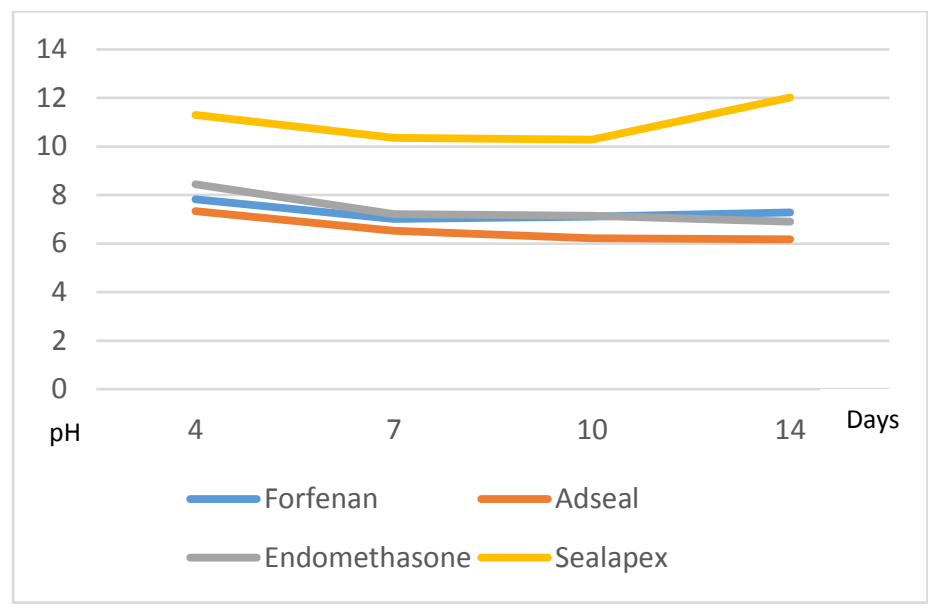

Figure 8. Graph of $p \mathrm{H}$ changes of the tested materials

The last parameter examined was flow rate. The diagonals and the area occupied by the material were measured. Sealapex showed the highest flow rate, while Endomethasone showed the lowest (Figure 9).

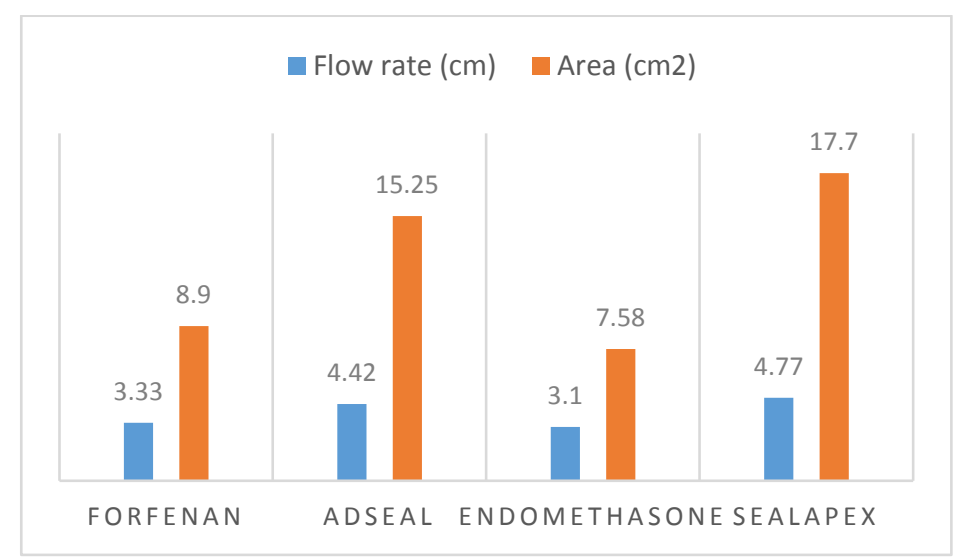

Figure 9. Flow rate of the examined sealer samples

A group of researchers investigated the physical and chemical properties of some endodontic sealers, including the solubility of Sealapex and Endomethasone. Samples of sealers were placed in artificial saliva, and measurements were taken again after 24,48 and $72 \mathrm{~h}$ soaking. Sealapex has been shown to have a lower dissolution rate compared to Endomethasone [9], which is in agreement with the results of this study.

Another study investigated the solubility of Adseal, among many other sealers. Samples were placed in $20 \mathrm{ml}$ deionized water and incubated at $37{ }^{\circ} \mathrm{C}$. Samples were allowed to dry for 24 hours before measurements. Based on the results obtained, Adseal samples were found to have increased their mass [3]. The increase in the mass of Adseal samples is also supported by the results of the present study. Other researchers also significantly show that Adseal is increasing in weight and volume and has the lowest solubility among the substances they studied [2].

We have also found several studies on Endomethasone, which report that this sealer shows high dissolution values in vitro [5,8].

We found little research on the physical properties of Forfenan. The effect of various solutions used in endodontic treatments on Forfenan has been assessed in a Commonwealth University of Virginia study on 49 extracted teeth filled with Forfenan. The results show that some solutions cause weight loss with Forfenan [10]. 
For a long period of time, one of the most popular sealers in some European countries was Endomethasone. It's still used today, but more and more modern sealers with lower solubility tend to replace it.

Another important parameter of any endodontic sealer is its $p \mathrm{H}$ and the literature abound with studies that deal with this characteristic. One study investigated the physicochemical properties of Adseal, along with two other sealers. Samples were stored in distilled water. The $p \mathrm{H}$ of Adseal slightly increased from baseline (6.4) and then stabilized at $p \mathrm{H} 6.5$ on day 14 and exhibited the highest flow rate $(23 \mathrm{~mm})$ [11]. In the present study, the $p \mathrm{H}$ of Adseal stabilized at 6.2. Other research groups assessed in their studies the $p \mathrm{H}$ changes for Endomethasone [9,12], similar to the results of the present study. Another study revealed the fact that Sealapex has the highest average $p \mathrm{H}$ value [13]. This result is supported by the present study.

Studies regarding the flow rate of Endomethasone and Sealapex are also available in the scientific literature. In one of these studies twenty grams of sealer were placed on a glass slab and a load of 100 $\mathrm{g}$ was placed on it for $3 \mathrm{~min}$. Sealapex showed no measurable results, and Endomethasone showed a diameter of approximately $30 \mathrm{~mm}$ [8], which is consistent with our results. In the case of Sealapex, however, a diagonal of $4.77 \mathrm{~mm}$ was measured. The flow rate, as well as the ability of the sealer to wet the surface are properties that determine the ability of the sealer to adhere to the root canal wall [14]. The ability to wet the root canal surface was not investigated in the present study, but further researches are planned.

\section{Conclusions}

Four commonly used root canal sealers were investigated in order to be recommended for their use and their physicochemical properties have been determined. Examination of the results revealed that Endomethasone had the highest solubility and lowest flow rate among the four sealers tested. Forfenan showed a moderate solubility, while Sealapex had the highest flow rate and highest $\mathrm{pH}$. Adseal showed the lowest $\mathrm{pH}$ but exhibited the lowest values in solubility. As such, it seems reasonable to conclude that Adseal might be the most suitable for use in clinical setting.

\section{References}

1.AHUJA, L., JASUJA, P., VERMA, K.G., JUNEJA, S., MATHUR, A., WALIA, R., KAKKAR, A., SINGLA, M., J Clin Diagn Res, 10, nr. 7, 2016, p. ZC76-ZC79.

2.SONG, Y.S., CHOI, Y., LIM, M.J., YU, M.K., HONG, C.U., LEE, K.W., MIN, K.S, Restor Dent Endod, 41, nr. 3, 2016, p. 189-195.

3.SAWSAN, T., ABEER, A., J Trauma Treat, 4, nr. 2:249, 2015, pg. 1-4.

4.FAZEKAS, A., Megtartó fogászat és endodoncia, Semmelweis, Budapest, 2006, p. 334-340.

5.POGGIO, C., ARCIOLA, C.R., DAGNA, A., COLOMBO, M., Int J Artif Organs, 33, nr. 9, 2010, p. $676-681$.

6.ROSA, P.C.F., MANCINI, M.N.G., CAMARGO, S.E.A., GARRIDO, A.D.B, CAMARGO, C.H.R, RODE, S.M., Braz Dent J, 21, nr. 4, 2010, p. 301-304.

7.ALZKRAIT, H., TAHA, N.A., HASSOUNEH, L., Braz Oral Res, 30, nr. 1, 2016, p. E16.

8.MARIN-BAUZA, G.A., SILVA-SOUSA, Y.T., DA CUNHA, S.A., RACHED-JUNIOR, F.J.A., BONETTI-FILHO, I., SOUSA-NETO, M.D., MIRANDA, C.E.S., J Appl Oral Sci, 20, nr. 4, 2012, p. 455-461.

9.SĂLCEANU, M., MELIAN, A., TUDOR, H., AMINOV, L., VATAMAN, M., Journal of Oral Rehabilitation, 5, nr. 1, 2013, p. 41-44.

10.MADELIN, G.G., The effect of endodontic solutions on resorcinol-formalin paste in teeth, Virgina Commonwelth University, 2003, Thesis and Dissertations.

11.YOO-SEOK, S., YOORINA, C., MYUNG-JIN, L., MI-KYUNG, Y., CHAN-UI, H., KWANGWON, L., KYUNG-SAN, M., Restor Dent Endod, 41, nr. 3, 2016, p. 189-195. 
12.GIUROIU, C.L, ANDRIAN, S., PASCA, A.S., FATU, A.M., VASCU, M.B., Rev Chim, 69, (9), 2018, 2443-2447.

13.KOVACS IVACSON, CS.A., CURT MOLA, F., BIRIS, C., BICA C.I., PACURAR, M., MONEA, A., Rev Chim, 68, (11), 2017, 2610-2613.

14.CARMEN TODEA, C., MOCUTA, D., MANESCU, A., SEMEZ, G., GIULIANI, A., LUCA, R., OGODESCU, A., Rev Chim, 69, (8), 2018, 2144-2149.

$\overline{\text { Manuscript received: } 28.11 .2019}$ 